friend and associate; that we will attend the funeral in a body, and wear the usual badge of mourning during the residue of the present term of the District court.

"Resolved, That the Secretary of this meeting transmit a copy of these proceedings to the family of the deceased, and assure them of our sincere condolence in this their hour of grief.

"Resolved, That these proceedings be presented to the District and Circuit courts of this county, with the request that they be spread upon the minutes of said courts.

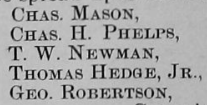

Committee.

After which followed remarks by Hon. Chas. H. Phelps, Hon. T. W. New man, A. M. Antrobus, W. E. Blake, D. Y. Overton, Thomas Hedge, Jr., C. B. Jack, Geo. E. Hubbell, of Davenport, Ia., W. W. Baldwin, Chas J. Dodge and others, being beautiful and touching tributes to the memory of the deceased, following which remarks the above resolutions were unanimously adopted."

\title{
THE HIGHEST CHURCH EDIFICE IN THE MOUNTAINS
}

An extract from a late letter of Rev. William Hamilton: "Irwin is high in the mountains, at an altitude of eleven thousand five hundred feet. It is on the western slope of the Rocky Mountains, ninety miles from Poncha Springs. To get here I crossed the continental divide in an open sleigh drawn by four horses, and rode over snow thirty teet deep. I suffered much, but a few days of rest and care restored me to my usual heaith and comfort.

"Here the snow is everywhere from eight to ten feet deep, and we have had many stormy days, snowing and blowing fully two weeks continuously; but I have succeeded beyond my expectations. The good hand of the Lord seems to be upon me, verifying the promise, 'As thy day is, so shall thy strength be.'

"I preach twice every Sabbath, and teach a class of adults, ladies and gentlemen, in the sabbath school, and yet I never preached with more comfort in my life. * * * * I have been here one month. Many houses are buried in the snow, and those occupied are reaclicd hy a passage kept open through the snow. Some houses are gradually coming to view as the snow settles and melts. **** This is the highest church in the United States, with mountains close at hand, rising three or four thousand feet above it; and the mountains are rich in silver, with immense beds of coal, both anthracite and bituminous, in the immediate vicinity. I find myself very kindly received here, and think there is an open field for much usefulness. I am happy in my labor and feel encouraged to work with all my strength, hoping and trusting in God to make my work successful."

It is with sad emotions that the editor of this work parts with his old friend, who labored, many years ago, side by side with him, at Addison, and his survivor then at Painted Post, Steuben county, N. Y. 
Copyright of Annals of Iowa is the property of State of Iowa, by \& through the State Historical Society of Iowa and its content may not be copied or emailed to multiple sites or posted to a listserv without the copyright holder's express written permission. However, users may print, download, or email articles for individual use. 